Int. J. Electrochem. Sci., 11 (2016) 8046 - 8056

\title{
Microstructure Evolution and Corrosion Behavior of Duplex Stainless Steel During Isothermal Aged at $650{ }^{\circ} \mathrm{C}$
}

\author{
Liang $\mathrm{He}^{1,2}$, Xiayu $\mathrm{Wu}^{2}$, Ziying Zhang ${ }^{1}$, Jin $\mathrm{Li}^{2, *}$ \\ ${ }^{1}$ School of Materials Engineering, Shanghai University of Engineering Science, Shanghai 201620, \\ China \\ ${ }^{2}$ Department of Materials Science, Fudan University, Shanghai 200433, China \\ *E-mail: corrosion@ @udan.edu.cn
}

doi: $10.20964 / 2016.09 .62$

Received: 21 June 2016 / Accepted: 28 July 2016 / Published: 7 August 2016

\begin{abstract}
Duplex stainless steel are used extensively for both strength and corrosion performance, but owing to its complex dual phase structure, there will be a variety of precipitation phases in the procedure of thermal process. In the present paper, the precipitation evolution and corrosion behavior of SAF2205 isothermal aged at $650{ }^{\circ} \mathrm{C}$ for various aging times up to $100 \mathrm{~h}$ was investigated. The microstructure evolution showed that with the increased of aging time, some chromium-rich intermetallic phase will precipitation and increased yet. The precipitation included intermetallic $(\sigma, \mathrm{R}, \tau, \chi)$, carbide and nitride $\left(\mathrm{Cr}_{2} \mathrm{~N}\right.$ and $\left.\mathrm{M}_{23} \mathrm{C}_{6}\right)$. DL-EPR test show a good relationship between microstructure and selective corrosion resistance. Simultaneously, on the basis of the EIS measurements the charge transfer resistance and interface adsorption time was obtained and both of which are decreased accompany the increasing of the aging time. The selective corrosion is associated with the chromium and molybdenum depleted zones formed around the precipitates during aging.
\end{abstract}

Keywords: duplex stainless steel, sensitization, precipitates, intergranular corrosion, EIS

\section{FULL TEXT}

(C) 2016 The Authors. Published by ESG (www.electrochemsci.org). This article is an open access article distributed under the terms and conditions of the Creative Commons Attribution license (http://creativecommons.org/licenses/by/4.0/). 